\title{
FIRST AMENDMENT CLAIMS AGAINST PUBLIC BROADCASTERS: TESTING THE PUBLIC'S RIGHT TO A BALANCED PRESENTATION
}

\section{INTRODUCTION}

First amendment doctrine, in accommodating government regulation of broadcasters, emphasizes the right of viewers and listeners to receive ideas. In determining the contours of this right, the Supreme Court sometimes has restricted broadcasters' traditional free press rights. ${ }^{1}$ As

1. Both public and commercial broadcasting differ substantially from the print media in terms of first amendment protection from government censorship. Whereas newspaper publishers clearly are protected from government interference by the press clause, New York Times Co. v. United States, 403 U.S. 713, 725 (1971) (Brennan, J., concurring), all broadcasters are subject to federal hicensing requirements and content regulation by the Federal Cominunications Commission (FCC). Red Lion Broadcasting Co. v. FCC, 395 U.S. 367, $379-80$ (1969). An interesting contrast exists between the Supreme Court's treatment of newspaper publishers and its treatment of broadcasters, compare Miami Herald Publishing Co. v. Tornillo, 418 U.S. 241, 259 (1974) (White, J., concurring) (" $[T]$ he First Amendment erects a virtually insurmountable barrier between governinent and the print media so far as government tampering, in advance of publication, with news and editorial content is concerned.") and New York Times Co. v. Sullivan, 376 U.S. 254, 270 (1964) (Court recognized "a profound national commitment to the principle that debate on public issues should be uninhibited, robust, and wide-open") with Red Lion, 395 U.S. at 388-89 (denial of broadcasting license because "public interest" requires it, is not an abridgement of free speech) and Columbia Broadcasting Sys. v. Demoeratic Nat"l Comm., 412 U.S. 94, 126 (1973) (limited government surveillance permitted in broadcasting media but not in private print media).

The Court's disparate treatment of the electronic media usually is explained in terms of the historical and technological development of the industry. Congress created the FCC licensing system in the 1930s as the best possible solution to technologieal limitations on the availability of electromagnetic frequencies (or spectrum) for radio broadcasting and, twenty years later, television broadcasting. See id. at 103-14; Red Lion, 395 U.S. at 375-86; National Broadcasting Co. v. United States, 319 U.S. 190, 210-17 (1943); FCC v. Sanders Bros. Radio Station, 309 U.S. 470,474 (1940); FCC v. Pottsville Broadcasting Co., 309 U.S. 134, 137-38 (1940); see also W. VAN ALSTYNE, INTERPRETATIONS OF THE FIRST AMENDMENT 70-71 (1984). Since the airwaves were regarded as a public trust and interference from stations broadcasting on the same frequency made them useless to everyone, the licensing solution was adopted to allocate channels in protection of the "public interest." National Broadcasting Co., 319 U.S. at 227 (holding that the licensing system was a proper exercise of Congress's power over commerce and that denial of a license was not a denial of free speech).

In response to this solution, the federal courts have developed a special, highly stylized first amendment analysis for public and commercial broadcasters that accommodates the licensing and regulatory authority of the FCC. Red Lion, 395 U.S. at 386; see W. VAN ALSTYNE, supra, at 73-77 (contrasting Red Lion and Miami Herald Publishing Co. to argue that the Supreme Court has distinguished broadcasting from the traditional press); FCC v. League of Women Voters, 468 U.S. 364, 376 (1984) (Supreme Court decisions dealing with broadcasting take different approach than those involving print media). 
Justice White concluded in Red Lion Broadcasting v. FCC: "It is the right of the viewers and listeners, not the right of the broadcasters, which is parainount." 2 The Supreine Court in FCC v. League of Women Voters identified this paramount right as "the public's First Amendment interest in receiving a balanced presentation on diverse matters of public concern." 3 By choosing this phrase, the Court captured the idea that the public's free speech interest in broadcasting is a collective right. As the court had suggested previously in the Red Lion case: "[T] he people as a whole retain their interest im free speech by radio [and television] and their collective right to have the medium function consistently with the ends and purposes of the First Amendment." 4 Thus, in the Supreme Court's atteinpts to sort out the various first amendment interests at stake-the broadcasters' and the public's interests-the Court has settled on protecting the public's interest primarily as a collective right of access to a variety of ideas, rather than a right of individual access or individual determination of program content. ${ }^{5}$ And limited as this collective right may be, ${ }^{6}$ the public continues to retam it even though individual free speech interests im broadcasting largely have been relimquished by legislative decision to a government-regulated imdustry.

The public's collective first amendment right is connected to the important social policy of promoting diversity on the airwaves-the same policy motivating inuch of the Federal Cominunications Commission's (FCC) broadcasting regulations. The market theory of ideas, a bedrock principle of first amendment doctrine, maintains that public access to a diversity of freely expressed ideas will advance the cause of truth, rather than retard it. The Supreme Court, in the context of broadcast regulations, has pointed to this theory as a justification for FCC regulation protecting the public's collective right of access:

[Because it] is the purpose of the First Amendment to preserve an uminhibited marketplace of ideas in which truth will ultimately prevail, ... the right of the public to receive suitable access to social, political, aesthetic, moral, and other ideas and experiences [through the medium

2. Red Lion, 395 U.S. at 390 (8-0 decision, Douglas, J., took no part in decision) (emphasis added).

3. League of Women Voters, 468 U.S. at 380.

4. Red Lion, 395 U.S. at 389-91 (emphasis added).

5. See also Columbia Broadcasting Sys., 412 U.S. at 105, 110, 124 (rejecting full or limited right of access and acknowledging licensees' editorial responsibilities). The interests of the individual to access ideas and select programs may be satisfied by the ever-expanding availability of channels-particularly through cable broadcasting - that allow some degree of individual preference in program selection. See infra text accompanying notes 45-46.

6. See infra notes 115-24 and accompanying text. 
of broadcasting] is crucial here [and it] may not constitutionally be abridged. ${ }^{7}$

This free market theory, however, is not entirely consistent with government regulation of broadcasting. With the interfering apparatus of government hicensing and content regulation, the broadcasting media simply cannot provide a market of ideas that is in any sense free. And the FCC's efforts to promote public access to a variety of ideas on the airwaves have been only arguably successful, while strapping the media with more regulation of content and imcreased competition for licenses. ${ }^{8}$

Government regulation of broadcasting, through station licensing and the content regulation that accompanies it, increasingly has come under attack. Critics argue that broadcast regulation is not effective in promoting free speech because regulation restricts broadcasters' exercise of discretion im program selection, restrains broadcasters froin expressing controversial viewpoints that might offend the public or the regulators, and no longer remains tenable based on spectrum scarcity or technological limitations. 9 Some critics also propose that broadcasters should be market participants rather than commumity trustees, ${ }^{10}$ since anything beyond minimal regulation is appropriate only if there is market failure in the industry. Under this marketplace approach, the FCC would rely on the broadcasters' ability to serve commumity interests tlirough normal market mechamisms, thereby reducing the need for government involvement and allowing the public to protect its own first amendment interests by switching channels.

In combination with reduced regulation, courts should recognize a cause of action based on the public's collective first amendment right. Such a cause of action would counteract the natural advantage broadcast licensees enjoy vis-a-vis the public in deciding what will be available on the airwaves by enabling listeners and viewers who are affected by broadcasters' programming decisions to challenge those decisions on first amendment grounds. By placing the initiative for redress in the hands of parties injured by a broadcaster's decision, this cause of action would shift some of the FCC's watchdog responsibilities to the public, whose interest in protecting its collective right of access is the strongest. Recog. nition of this right would have the same purpose, the preservation of first amendment values, as the "public interest" standard-the statutory re-

7. League of Women Voters, 468 U.S. at $377-78$ (quoting Red Lion, 395 U.S. at 390).

8. For an extensive discussion of how the commercial broadcasting industry would benefit from deregulation and the substitution of a market approach, see Fowler \& Brenner, $A$ Marketplace Approach to Broadcast Regulation, 60 TEX. L. REV. 207 (1982).

9. For a general treatment of the dangers of broadcast regulation, see $L$. PowE, AMERICAN BROADCASTING AND THE FIRST AMENDMENT (1987).

10. See Fowler \& Brenner, supra note 8, at 209-10. 
quirement that guides the FCC to select licensees and promulgate regulations when "public convenience, interest, or necessity will be served."11 But despite a common purpose, ${ }^{12}$ the public interest standard differs from a cause of action based on the public's right to a balanced presentation because the standard merely provides a constraint on agency action, whereas a right to a balanced presentation cognizable by the courts entitles an injured party to a remedy at law. The right to a balanced presentation also differs from the controversial "fairness doctrine"-an FCC policy, currently abandoned, requiring broadcast licensees to provide fair treatment on issues of public concern. ${ }^{13}$ The fairness doctrine was only an agency policy and, like the public interest standard, rarely was adjudicated outside the context of hicense renewal hearings. ${ }^{14}$ And finally, the courts' recognition of the public's right to a balanced presentation also

11. 47 U.S.C. $\$ \S 307(a), 309$ (a) (1982).

12. The FCC now views the public interest "through First Amendment lenses" as a result of a historical intertwining of the public interest standard and first amendment interests. Syracuse Peace Council v. FCC, 867 F.2d 654, 674 (D.C. Cir. 1989), cert. denied, 110 S. Ct. 717 (1990). Chief Justice Burger also has acknowledged the public interest standard as statutory security for first amendment doctrine in broadcasting: "The 'public interest' standard necessarily invites reference to First Amendment principles." Columbia Broadcasting Sys., 412 U.S. at 122.

13. The fairness doctrine requires that radio and television broadcast licensees devote a reasonable portion of programming to discussion of controversial issues of public concern and, in doing so, afford a reasonable opportunity in overall programming for the presentation of contrasting views. In re Applications of City of N.Y., Municipal Broadcasting Sys., 56 F.C.C.2d 169, 170 (1975); see Columbia Broadcasting Sys., 412 U.S. at 111; Red Lion, 395 U.S. at 369. Since adopting the fairness doctrine, the FCC's policy has been to allow broadcasters "wide journalistic discretion" and to limit the agency to a determination of whether the licensee acted "reasonably and in good faith." In re Patsy Mink, 59 F.C.C.2d 987, 994 (1976); see also Fairness Doctrime and Public Interest Standards, 39 Fed. Reg. 26,372, 26,374 If 15 (1974); Fairness Doctrine Primer, 40 F.C.C. 598, 599 (1964); Report on Editorializing by Broadcast Licensees, 13 F.C.C. 1246, 1249 (1949).

The fairness doctrine was promulgated first as an FCC policy, and its scope was delineated in a series of FCC rulings. Although it serves some of the same purposes, the fairness doctrine is distinct from the statutory requirement of the Communications Act $(\S 315)$ requiring broadcasters to provide equal time to all qualified candidates for public office. Red Lion, 395 U.S. at 369-70. The Supreme Court has examined only a few FCC fairness doctrine rulings and, in all cases, has upheld them on constitutional grounds. See, e.g., id. at $\mathbf{3 7 5}$ (fairness doctrine requires free reply time for personal attacks and reasonable response time for political editorializing); Columbia Broadcasting Sys., 412 U.S. at 123 (upholding FCC determination that fairness doctrine does not require right of access for editorial advertisements).

In 1987 the FCC announced that the fairness doctrine would not be enforced as an agency regulation. Whereas the doctrine originally had been introduced as a measure protecting first amendment rights, the FCC, under the leadership of Reagan appointees Mark Fowler and Dennis Patrick, concluded that first amendment interests are best served by deregulation. Compare Fairness Doctrine and Public Interest Standards, 39 Fed. Reg. 26,372, 26,373 (1974) ("[t]he purpose and foundation of the fairness doctrine is ... that of the First Amendment itself") with Inquiry into Alternatives to the General Fairness Obligations of Broadcast Licensees, 102 F.C.C.2d 143, 148 (1985) (Counmission "finnly convinced that the fairness doctrine, as a inatter of policy, disserves the public interest .....").

14. See Columbia Broadcasting Sys., 412 U.S. at 110. 
differs from the "strict objectivity" standard-a standard that is applicable only in public broadcasting. ${ }^{15}$ This standard is a statutory "goal," a "guide to Congressional oversight policy," for legislative supervision of public broadcasting; it is not a right legally enforceable by courts or the FCC. 16

Recogmition of the public's right to a balanced presentation, enforceable in court, is particularly important with respect to public broadcasting because of the government's role in that area as broadcaster. ${ }^{17}$ The majority of public stations are licensed to state and municipal agencies ${ }^{18}$ who consequently control the the stations and hold the possibility of propagating their own views, disguised as viewpoint-neutral newscasts, and promoting programs that present state and local government in a favorable light. This power potentially enables the government to overpower non-governmental voices through the credibility and authority that government speech implies, thereby diminishing diversity and further restraining the marketplace of ideas. ${ }^{19}$ Market forces alone, moreover, cannot correct such abuses in public broadcasting, as they might in commercial broadcasting, since commercial stations really do not compete with public stations because of notable differences in programming, and the fact that few localities receive more than one or two public stations. 20

\footnotetext{
15. See 47 U.S.C. $\$ 396(\mathrm{~g})(1)(\mathrm{A})(1982)$.

16. Accuracy in Media, Inc. v. FCC, 521 F.2d 288, 297 (D.C. Cir.), cert. denied, 425 U.S. 934 (1975).

17. This Note considers the terms "public broadcaster," "noncommercial broadcaster," and "educational broadcaster," interchangeable in refering to a television or radio station that the FCC licenses to a (1) nonprofit foundation, corporation, or association, (2) state or political or special subdivision of a state, or (3) municipality for the purpose of disseminating educational and cultural programs to the public. See 47 U.S.C. $\$ 397(6),(7)(1982)$.

18. See infra notes 103-12 and accompanying text.

19. For a general discussion of the overpowering effect of government speech, see M. YUDOF, When Government Speaks: Polmics, LAW AND Government Expression in America (1983); cf. Note, The Voice of Government as an Abridgement of First Amendment Rights of Speakers: Rethinking Meese v. Keene, 1989 DUKE L.J. 654 (discussing propaganda labeling by the federal government as government speech). Although all broadcast licensees, like the traditional press, are charged with a "historic, dual responsibility" of reporting information and bringing critical judgment to bear on public affairs, government licensees operate with an inherent conflict of interest. See FCC v. League of Women Voters, 468 U.S. 364, 382 (1984). Public broadcasters, particularly when they effectively delegate editorial discretion to professional journalists, may perform both these responsibilities admirably. The government licensee's abuse of either responsibility, however, must be challengeable in court by parties injured by such abuses-members of the viewing or listening public.

20. Corporation for Public Broadcasting, Public Broadcasting Statistics in BRIEF 2 (Spring 1989) [hereinafter STATISTICs]. According to the CPB statistics, seventy-two percent of the American population receives two or fewer public television stations and seventy-eight percent receives two or fewer public radio stations. Id. The primary difference in format between commercial and noncommercial stations is the absence of advertisements on public stations. See 47 U.S.C. $\S 399(b)(2)$.
} 
Claims brought in federal court against public broadcasters based on the public's collective first amendment right to a balanced presentation provide a neans of checking potential government abuses. These claims would rely on the injured party's initiative and require a licensee to defend his infringing action in terms of a substantial government interest. ${ }^{21}$ Most likely, viewers would be restrained to litigate these actions only against government licensees of public stations because the first amendinent protects the public from the government's abridging conduct, and the Supreme Court has not found sufficient government involvement in commercial broadcasting to inake non-governinental hicensees vulnerable to first amendment challenges. 22

Tlins Note analyzes the possibility of a cause of action against public broadcasters based on the public's collective right to a balanced presentation. Since the strength of the public's right results from the restrictive presence of government regulation, tlns Note first exammes the statutory scheme governing public broadcasters, focusmg on FCC licensing and regulation and Congress's funding mechanisins for public broadcastingthe Corporation for Public Broadcasting (CPB). ${ }^{23}$ In Part II, the Note discusses the Constitution's state action requirement for all first amendment claims, mcludimg claims against public broadcasters. This Part argues that government licensees (and therefore inost public station licensees) ${ }^{24}$ are subject to such claims according to the state action doctrime. Part II then proposes a standard by which courts should evaluate claims based on the public's collective first amendment right. Under the proposed standard, the government's infringing conduct can withstand attack only if its conduct is narrowly tailored to further a substantial government interest. ${ }^{25}$ Finally, Part III demonstrates the standard's apphication in the context of three hypothetical cases. ${ }^{26}$

In a special concurrence in Muir v. Alabama Educ. Television Comm., 688 F.2d 1033, 1050 (5th Cir. 1982) (en banc), cert. denied, 460 U.S. 1023 (1983), Judge Rubin pointed out potential differences among public stations depending on their functions; he described the defendant public stations as "serv[ing] . . . a diet that differs from commercial television primarily in appeal to a somewhat more sophisticated audience, the absence of commercials, and efforts to raise funds from viewers." Id. This description fits a large number of public television and radio stations.

21. See infra notes $125-42$ and accompanying text.

22. See infra notes $76-89$ and aceompanying text. For a general discussion of the state action doctrine as it pertains to commercial broadcasting, see Walden, The Applicability of State Action Doctrine to Private Broadcasters, CoMM/ENT L.J. 265 (1985).

23. See infra notes $27-75$ and accompanying text.

24. See infra notes $76-114$ and accompanying text.

25. See infra notes 125-142 and accompanying text.

26. See infra notes 143-165 and aceompanying text. 


\section{Federal Regulation of Public Broadcasting}

\section{A. The FCC and the Broadcast Licensing System}

In the Federal Communications Act of 1934 (Communications Act), Congress established federal control of all broadcasting ${ }^{27}$ by creating the FCC and giving it authority to enforce and execute the statutory provisions. $^{28}$ Congress also ensured public compliance with federal licensing and regulatory requirements by authorizing stiff penalties for violations of the Communications Act or FCC regulations. ${ }^{29}$

The 1934 Communications Act gives the FCC responsibility for allocating licenses and construction permits to broadcasters. ${ }^{30}$ Since it forbids any radio or television transmission without an FCC license, ${ }^{31}$ every radio and television station must apply for a license and follow the agency's license renewal procedures. The license application requires information about a proposed station such as its purpose, broadcast schedule, frequency and power, as well as information about the applicant herself, mcluding her citizenship, character, and technical proficiency. ${ }^{32}$ And if a broadcaster refuses to operate a station in accordance with the purpose specified in the license or with agency policies regulating the station's broadcasts, then the FCC has statutory authority to revoke its hicense. ${ }^{33}$

Through the Communications Act's public interest standard, Congress set an important guideline for the FCC in exercising its discretion to grant and renew licenses. This standard allows the agency to grant licenses and regulate broadcasting "as public interest, convenience, or necessity requires." 34 Although most applicants satisfy this minimal standard, the Communications Act, as amended, provides other, more specific guidelines for close cases. For example, if more than one applicant requests the same channel, then the FCC must determine which applicant will best serve the public interest. ${ }^{35}$ Additionally, if the appli-

27. Act of June 19, 1934, ch. 652,48 Stat. 1064 (codified as amended at 47 U.S.C. $\$ \S 151-610$ (1982 \& Supp. V 1987) (Communications Act of 1934)).

28. 47 U.S.C. $\S \S 151,154$ (i) (1982). The FCC can exercise its authority through administrative rulemaking, id. § 151, as well as adjudication, $i d$. $\$ 208$; see also id. $\$ 401$ (granting federal district courts jurisdiction to enforce compliance with statutory provisions or FCC orders).

29. Any person who willfully and knowingly violates the provisions of the Act may be subject to a fine of up to $\$ 10,000$ and/or imprisonment of up to one year. Id. $\S 501$. Violation of any FCC regulation carries a maximum penalty of $\$ 500$ for every day the offense occurs. Id. $\S 502$.

30. Id. $\S \S 307,319$.

31. Id. $\S 301$.

32. Id. § 308(b).

33. Id. $\S 312(\mathrm{a})(3),(4)$ (1982 \& Supp. $\mathrm{V} 1987)$.

34. Id. $\S \S 307(\mathrm{a}), 309$ (a) (1982).

35. For a discussion of the FCC's "comparative renewal" process, see Note, Simon Geller and the Comparative Renewal Process: What's Good for Gloucester?, 6 CoMM/ENT L.J. 185, 191 (1983). 
cants are equally qualified, the agency must select randomly among them in order to award the license. ${ }^{36}$ To guard against uniformity of broadcasting, Congress requires that the FCC give "preference" to those applicants who would bring diversity to the airwaves. ${ }^{37}$ Congress has amended the Communications Act to further emphasize diversity of ownership and to instruct the agency to give "additional significant preferences" to applications of specific "minority group[s]." 38

A provision in the Communications Act also clarifies that the FCC lias no power to censor programs or curtail free speech riglits associated with broadcasting. ${ }^{39}$ The Supreme Court, however, in reviewing the constitutionahty of FCC action routinely has sanctioned the agency's exercise of broad discretionary powers in supervising station operation and regulating program content. The Court has upleeld limitations on station networking, ${ }^{40}$ FCC regulation of cable television, ${ }^{41}$ and FCC prohibitions on cross-media ownership. ${ }^{42}$ In cases more directly involving content regulation, the Court has approved the agency's application of the fairness doctrine and the right-of-reply requirement to political candidates, ${ }^{43}$ its refusal to mandate an access riglt for editorial advertisements, ${ }^{44}$ and its prohibition of "indecency" on airwaves during daytimie hours. ${ }^{45}$

Congress originally developed a regulatory scheme in order to promote broadcasting and administer the limited spectrum as a scarce public resource by ensuring the allocation of licenses im a fair and efficient manner. Under this admimistrative scheme, Congress delegated substantial

36. 47 U.S.C. § 309(i) (1982).

37. Id. $\S 309(\mathrm{i})(3)(\mathrm{A})$.

38. Id. The Communications Act defines "minority group" to include Blacks, Hispanics, American Indians, Alaska Natives Asians, and Pacific Islanders. Id. § 309 (3)(C)(ii).

39. Section 326 provides: "Nothing in this chapter shall be understood or construed to give the Commission the power of censorship ... and no regulation or condition shall be promulgated or fixed by the Commission which shall interfere with the right of free speech ...." Id. $\$ 326$ (1982).

40. National Broadcasting Co. v. United States, 319 U.S. 190, 226-27 (1943).

41. United States v. Southwestern Cable Co., 392 U.S. 157, 178 (1968); see also United States v. Midwest Video Corp., 406 U.S. 649, 663, 666 (1972) (FCC may require cable systems to carry local broadcasts to encourage programming initiative and satisfy community needs). But see Midwest Video Corp. v. FCC, 571 F.2d 1025, 1038 (8th Cir. 1978), aff'd, 440 U.S. 689, 709 \& n.19 (1979) (FCC rule requiring that cable systems set aside channel for public access exceeds FCC authority; Court thus declined to rule on first amendment issue).

42. FCC v. National Citizens Comm. for Broadcasting, 436 U.S. 775, 779, 802 (1978); see also Note, Eliminating the Network/Cable Cross-Ownership Ban: Does a Free Market Protect the Marketplace of Ideas?, 6 COMM/ENT L.J. 163, 164 (1983) (in light of FCC interest in eliminating ban, a separate market analysis is required to determine whether network/cable cross-ownership ban incrcases or decreases diversity of views).

43. Red Lion Broadcasting Co. v. FCC, 395 U.S. 367, 370, 400 (1969).

44. See Columbia Broadcasting Sys. v. Democratic Nat'l Comm., 412 U.S. 94, 129, 132 (1973).

45. FCC v. Pacifica Found., 438 U.S. 726, 738, 750-51 (1978). 
discretion to the FCC. As a result, the agency regularly exercises its authority to decide which stations meet the "public interest" in license apphications, evaluate whether stations have operated according to their purpose in licensee-renewal hearings, and more infrequently determine which stations have violated statutory provisions or agency policies. However, technological changes over the past twenty years, such as more efficient use of the available spectrum, better transmission facilities, and the growth in cable broadcasts, satellite dishes, and superstations, have reduced the necessity for such pervasive government regulation. ${ }^{46}$ In fact, in several recent broadcasting cases the Supreme Court noted that innovations during the past fifty years, such as cable, have eased the channel shortage that originally justified the licensing system. ${ }^{47}$ Despite these technological breakthroughs, the Court has decided to retain a doctrimal distinction between the broadcasting and print media in terms of hicensing and regulation until the FCC or Congress explicitly directs it to do otherwise. ${ }^{48}$ Thus, despite criticisin of the current regulatory system, ${ }^{49}$ technological progress has brought no sweeping changes.

This lack of change in broadcast regulation has frustrated both pubhic and cominercial broadcasters, who are equally concerned about the federal regulatory scheme's effect on the right of free expression. Public broadcasters must be concerned, for Congress has made no distinction in the regulatory scheme between types of broadcasters. ${ }^{50}$ Thus, the original 1934 Communications Act provisions, along with subsequent legislation directed at public broadcasters, cover public stations.

\section{B. The Corporation for Public Broadcasting}

Although Congress has promoted the development of educational broadcasting since 1939,51 the Public Broadcasting Act of 1967 (PBA)

46. See supra notes $1,5$.

47. See, e.g., FCC v. League of Women Voters, 468 U.S. 364, 376 n.11 (1984) (advent of cable and satellite television technologies provides "such a wide variety of stations that scarcity doctrine is obsolete"); Columbia Broadcasting Sys., 412 U.S. at 131 (advent of cable television has increased opportunities for discussion of public issues).

48. League of Women Voters, 468 U.S. at 376 n.11.

49. See supra notes 8-10 and accompanying text.

50. The Public Broadcasting Act of 1967 amended the Communications Act of 1934. Pub. L. No. 90-129, 81 Stat. 365 (codified as amended at 47 U.S.C. $\$ \S 390-399$ (1982 \& Supp. V 1987)); see also League of Women Voters, 468 U.S. at 367 (Congress originally made no special provisions for public broadcasting).

51. See id. at 367. Educational stations have operated since the advent of broadcasting in the United States. Id. In response to the competition generated by commercial stations, the FCC reserved a certain number of stations for educational radio in 1939. 47 C.F.R. $\$ \S 4.131-.133$ (1939). In 1952, the FCC also allocated certain television channels for educational stations. Television Assignments, 41 F.C.C. 148, 157-58 (1952). In 1962 Congress finally provided direct funding for the 
was the first major federal funding commitment to public broadcasting. ${ }^{52}$ Congress enacted the PBA following recommendations made by the Carnegie Commission on Educational Television..$^{53}$ Congress authorized federal funding of public broadcasting because, as the Carnegie report noted, the development of public broadcasting for instructional, educational, and cultural purposes served the public interest. ${ }^{54}$ Public broadcasting, as Congress envisioned it, was to be a joint venture between the federal government and local stations. As the statute emphasized, the success of public broadcasting would require "freedom, imagination, and initiative" on local levels in addition to federal support. ${ }^{55}$

This legislation created the Corporation for Public Broadcasting (CPB) and established guidehines to protect public broadcasters from overreaching by the federal government. ${ }^{56}$ The CPB's primary responsibility is to distribute funds, budgeted by Congress on an annual basis, ${ }^{57}$ for construction of broadcasting facilities and development of "highquality" programming. ${ }^{58}$ The CPB is held accountable for its distributions and must present a detailed financial statement of its amiual spending to the General Accountimg Office for review. ${ }^{59}$ Despite this fiscal

construction of noncommercial television stations through the Educational Television Act of 1962, Pub. L. No. 87-447, 76 Stat. 64.

52. Compare Educational Television Act of 1962, Pub. L. No. 87-447, 76 Stat. 64, 65 (codified as amended at 47 U.S.C. $\$ \S 390-398$ (1982 \& Supp. V 1987)) (authorizing matching grants of $\$ 32$ million over five year period) with Public Broadcasting Act of 1967, Pub. L. No. 90-129, 81 Stat. 365,365 (codified as amended at 47 U.S.C. $\$ \S 390-398$ (1982 \& Supp. V 1987)) (authorizing $\$ 38$ million annually for construction and research grants).

53. See League of Women Voters, 468 U.S. at 368; CARNEGIE COMMISSION ON EDUCATIONAL Television, Public Television: A Program for Action (1967) [hereinafter Carnegie I]. The Commission was sponsored by the Carnegie Corporation of New York and endorsed by President Lyndon B. Johnson. Id. at vii. Its purpose was to "conduct a broadly conceived study of noncommercial television" and to "recommend lines along which noncommercial television stations might . . . develop during the years ahead." Id. The Carnegie Commission published its reappraisal of public broadcasting (this time, public television and radio) in the 1970s in A Public TRUST: THE

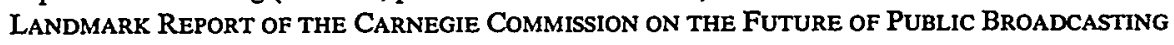
(1979) [hereinafter CARNEGIE II].

54. CARNEGIE I, supra note 53, at 13-14; see also 47 U.S.C. § $396(a)(1)$ (1982) ("it is in the public interest to encourage the growth and development of public radio and television broadcasting, including . . . use ... . for instructional, educational, and cultural purposes").

55. Id. $\S 396(\mathrm{a})(3)$.

56. See id. § $396(\mathrm{a})(7),(\mathrm{b})$.

57. 47 U.S.C.A. $\$ 396(\mathrm{k})(2)(B)$ (West Supp. 1989).

58. 47 U.S.C. $\$ 396(\mathrm{~g})(1)(\mathrm{A})(1982)$.

59. Id. $\S 396(l)$ (1982 \& Supp. V 1987). The Carnegie Corporation initially proposed that Congress establish a trust to fund the CPB through a manufacturers' excise tax of two to five percent on television sets. CARNEGIE I, supra note 53, at 8,68-69. The trust fund was advocated as an alternative to ordinary federal budget appropriations that would enable the CPB to operate free of government administrative regulations and avoid government oversight of day-to-day operations. Id. at 69 . The Commission expected $\$ 4$ million annually from private sources and foundations compared to the $\$ 60$ million per year the excise tax was expected to raise. Id. at 70,72 . Despite the Commis- 
supervision, the CPB was not designed to operate as a traditional government agency. ${ }^{60}$ Rather, the CPB was organized by Congress as a nonprofit corporation under District of Columbia law, ${ }^{61}$ forbidden from operating broadcast stations, ${ }^{62}$ and prohibited from producing, scheduling, or disseminating programs to the public.63 Thus, the CPB, under congressional design, operates as an independent intermediary between the federal government and public stations. ${ }^{64}$

1. The Public Broadcasting Service. In the PBA, Congress required the CPB to establish interconnection systems that would make available to affiliated stations all federally funded broadcast services and prograins. ${ }^{65}$ The CPB satisfied that statutory requirement by establishing the Public Broadcasting Service (PBS) and National Public Radio (NPR) as separate interconnection systems for public television and radio stations. ${ }^{66}$ These interconnection systeins operate as nonprofit corporations whose inembership is composed of public stations that receive direct grants and subscribe to CPB funded services. The member stations of PBS and NPR have access to any programs underwritten by $\mathrm{CPB}$ or produced by these interconnection systems.

Although the interconnection systems are structurally independent of the CPB, the responsibilities of the CPB and the interconnection systems often overlap. For example, the CPB and PBS both underwrite

sion's recommendation, Congress decided to fund the CPB through an annual appropriation to the "Public Broadcasting Fund" administered by the Secretary of the Treasury. 47 U.S.C. $\S 396(\mathrm{k})(1)(\mathrm{A}),(\mathrm{B})(1982)$. The amount appropriated is proportional to the non-federal support received by public broadcasters. Id. $\S 396(\mathrm{k})(1)(\mathrm{C})$ (1982 \& Supp. V 1987).

60. Id. $\S 396(\mathrm{~b})(1982)$.

61. Id. $\$ 396(\mathrm{~g})(3)$.

62. 47 U.S.C. $\S 396(\mathrm{~g})(3)(\mathrm{A})(1982)$.

63. Id. $\S 396(\mathrm{~g})(3)(\mathrm{B})$.

64. See FCC v. League of Women Voters, 468 U.S. 364, 388-89 (1984) (CPB's "elaborate structure" insulates local public stations from govenment interference); $c f$. Canby, The First Amendment and the State as Editor: Implications for Public Broadcasting, 52 TEx. L. REV. 1123, 1158-59 (1974) (arguing that although Public Broadcasting Service program production may constitute government censorship, CPB's funding decisions do not raise first amendment problems of content control).

65. 47 U.S.C. $\$ 396(\mathrm{~g})(1)(B)(1982)$.

66. Carnegie II, supra note 53, at 39. Despite the importance of NPR and PBS to the successful operation of public stations, the most serious constitutional challenge to the federal public broadcasting scheme centers on the activities of these interconnection systems. Since the majority of PBS members are state and local government entities, the government is involved in decisions regarding programming content whenever the interconnection systems sponsor programs. See Canby, supra note 64, at 1159 \& n.218. This involvement in program selection, an exercise of editorial discretion, arguably impinges on the independent operation of public stations. The systems' influence on programming content, however, is moderated by practical aspects of public broadcasting. Notwithstanding member stations' contributions, individual stations retain discretion to choose which programs are broadcast. Membership in PBS and NPR makes sponsored programs available, but stations are not compelled to broadcast any of these programs or services. 
programs for public broadcasters. The CPB retains authority to decide which programs it finances, although it has agreed to consult with PBS on these decisions. ${ }^{67}$ As an alternative to programs underwritten by the CPB, PBS soinetimes pools its meinber stations' funds and without approval of the CPB also produces programs for national distribution. ${ }^{68}$ Additionally, the funds of the two organizations ultimately are commingled. For instance, CPB and its nember stations partially fund PBS: CPB funds PBS's technical operations, ${ }^{69}$ although PBS ineinber stations contribute funds to finance PBS's programming, proinotion, research, and public information. ${ }^{70}$ And besides the CPB's direct funding of PBS, individual public stations may use their unrestricted $C P B$ grants to pay for programs underwritten by PBS. Despite the overlap of prograinming activity and funding, the PBS historically has been aligned more closely with the individual public stations than has CPB. PBS acts as an advocate of local stations' interests in federal lobbying efforts. ${ }^{71}$ PBS also impelled CPB to increase the amount of unrestricted grants, in effect limiting CPB's discretion in program funding. ${ }^{72}$

2. National Public Radio. NPR, the imtercomection system for public radio, operates differently than does PBS. Unlike PBS, NPR participates in the joint production (as well as distribution) of programs directly funded by CPB. ${ }^{73}$ All NPR program production is funded entirely by the CPB with no contributions from individual radio stations. As a result, competition between NPR and CPB does not exist to the saine

67. CARNEGIE II, supra note 53, at 47.

68. Id. Until 1973, national public television programs were funded largely by federal funds and supplemented by private sources. Id. at 1, 54-55. When the CPB and PBS were reorganized under the 1973 Partnership Agreement, a larger proportion of the funds were channeled directly to local stations. See id. at 155. PBS created the Station Program Cooperative (SPC) to pool programming funds for the use of the stations. Id. The SPC benefits from a national programming budget provided member stations but operates through a decentralized decision making process with several hundred station representatives. Id. The SPC accounts for forty percent of broadcasting hours. Id. at 155.56 \& n.5. Programs are produced by individual local stations and offered to the system in order to receive underwriting support. Id. at 156. Stations purchase the programs they use, and the cost is inversely proportional to the number of stations using the program. Id. at 155 n.5.

69. Id. at $46-47$.

70. $I d$.

71. See, e.g., Canby, supra note 64, at 1157-58 (discussing representation of local station's interests by PBS during Congress's attempts to persuade the CPB to drop some of its most controversial public affairs programs in 1973).

72. Id. at 47 . The CPB's discretionary funds are distributed directly to television stations as Community Service Grants. In 1987, nearly sixty-three percent of CPB's budget went directly to stations in the form of Community Service Grants (\$109.5 million to public television and \$34.1 million to public radio stations). See Corporation for Public Broadcasting, Catalyst in THE PUblic INTERest 24 (1989).

73. See CARNEGIE II, supra note 53, at 61. 
extent as the competition between CPB and PBS arising from their overlapping responsibilities, and individual public radio stations tend to support CPB's supervision of national prograin production. ${ }^{74} \mathrm{CPB}$ and NPR's cooperative interaction has resulted in high quality national public affairs programming that is funded directly by the CPB but produced largely without CPB interference. ${ }^{75}$

\section{Federal Regulation of Government Broadcasters and the Public's First Amendment Rights}

As set forth above, public broadcast stations are subject to FCC regulation and additional statutory requirements conditioning their receipt of CPB funds. Meanwhile, the intercounection services, PBS and NPR, protect public stations' interests (to varying degrees) and provide some programming produced almost entirely independent of federal governinent control. As a result of these intermediaries and specific legislation designed to insulate local public stations, the federal government is involved on the national level in only a limited manner.

Despite the limits on federal control, however, state and inunicipal governments are substantially involved in supervising inost public stations. The reason is because given the FCC's practice of licensing public stations to state and inunicipal government entities, these governinent bodies hold ultimate discretion over editorial decisions about prograinming. This discretionary power in the hands of the government gives rise to potential abuse-abuse covered as fully by the first amendment as the inore traditional restrictive effect that governinent regulation can have on free speech rights. Heretofore, this first amendment protection against abuse of government discretion has lain dormant. One way to check government prerogative in public broadcasting is for the courts to recognize claims against government licensees based on the public's right to a balanced presentation.

A clain based on the right to a balanced presentation raises several difficult first ainendment issues. The second Part of this Note addresses three primary issues raised by such a claim. First, how does a plaintiff demonstrate sufficient government involvement in public broadcasting to satisfy the first amendment's state action requirement? Second, under what standard should courts balance government interests with the pubhic's right to a balanced presentation? Third, which interests, among many legitimate government interests, are substantial enough to justify licensee conduct infringing the public's right to a balanced presentation?

\footnotetext{
74. See id.

75. See id.
} 
After addressing these three issues and deriving a standard for testing sucl claims, Part III of this Note illustrates the standard's application to three hypothetical cases.

\section{Weighing the Public's Rught to a Balanced Presentation Against GovernMENT INTERESTS}

\section{A. State Action in Public Broadcasting}

The first amendinent protects individuals' free speech riglits froin government infringement. Altlougli the first amendment's language expressly refers only to Congress-"Congress sliall make no law ... abridging the freedom of speecl, or of the press"76 - the amendment lias been interpreted also to protect those rights from infringeinent by federal agencies, and state and mumicipal governınents. ${ }^{77}$ Tlus, in order to invoke the first ainendment's protection, a plaintiff inust first demonstrate sufficient federal, state, or inunicipal governınent involveinent ("state action") in the infringing conduct. ${ }^{78}$

Before proceeding to a claim's merits, courts inust assess the sufficiency of government involvement by exainining the facts and circuunstances linking the government to an alleged first amendment violation. ${ }^{79}$ Whereas the Supreine Court's analysis considering the presence of state action in coininercial broadcasting is problematic, ${ }^{80}$ the case for governinent involvement in public broadcasting is more coinpelling. Federal, state, or inunicipal governments may be involved in public stations' oper-

76. U.S. CONST, amend I.

77. See generally J. Nowak, R. Rotunda, \& J. Young, Constitutional Law 421-50 (1986) (official act of any government agency is direct government action and subject to constitutional review). The first amendment's freedom of speech and of the press also have been incorporated into the fourteenth amendment, and this protects against infringement by the states. See Bridges v. California, 314 U.S. 252, 268 (1941); see also Gitlow v. New York, 268 U.S. 652, 666 (1925) (assuming the first amendment's applicability to the states through the fourteenth amendment).

78. See also Public Utils. Comm'n v. Pollack, 343 U.S. 451, 461 (1952) (first amendment restricts government, not private persons); Walden, supra note 22, at 268 (restraints on expression imposed by private parties are outside scope of the first amendment); $c f$. Marsh v. Alabama, 326 U.S. 501, 506 (1946) (private facilities operated primarily for public function subject to first amendment protection).

79. See also J. NowaK, R. Rotunda, \& J. Young, supra note 77, at 448 (Court's case-by-case analysis results in lack of predictability); $c f$. Burton v. Wilmington Parking Auth., 365 U.S. 715, 722 (1961) ("only by sifting the facts and weighing circumstances can the nonobvious involvement of the state in private conduct be attributed its true significance").

80. See infra notes 81-89 and accompanying text; see also Walden, supra note 22 (analyzing application of state action doctrine to private broadcasters in a first amendment context); Lange, The Role of the Access Doctrine in the Regulation of Mass Media: A Critical Review and Assessment, 52 N.C.L. REv. 1, 28 (1973) (in constitutional claims against broadcasters, courts demonstrate "a rather firm presumption against a finding of state action"). 
ations in three ways: (1) the FCC may impose hicensing requirenents and other regulations, or agencies on the state level also may regulate; (2) the $\mathrm{CPB}$ or state and local governments may provide funding; or (3) government hicensees may make editorial and operational decisions for the station. Although government hicensing, regulation, and funding of certain activities do not usually satisfy the state action requirement, the conduct of a public station, acting under authority of a state or local government hicensee, will likely constitute state action for first amendment purposes.

Although the federal government is involved in all public stations by virtue of FCC hicensing and regulation, that involvement is insufficient to satisfy the first amendment's state action requirement for claims against non-government broadcasters. In a commercial broadcasting case, $\mathrm{Co}$ lumbia Broadcasting System v. Democratic National Committee, a divided Supreme Court addressed the state action issue. ${ }^{81}$ In this case, the Democratic National Committee and the Business Executives' Move for Vietnam Peace challenged a commercial broadcaster's policy prohibiting editorial advertisements. ${ }^{82}$ The Court held that although the fairness doctrine and the public interest standard incorporate first amendment values, neither requires broadcasters to accept editorial advertiseinents. ${ }^{83}$

In a total of six filed opinions, however, the Court reached no consensus on the state action issue. A plurality of three Justices held that no state action existed (Chief Justice Burger and Justices Rehnquist and Stewart); ${ }^{84}$ two held that state action did exist (Justices Brennan and Marshall); ${ }^{85}$ one assumed state action for the sake of argument (Justice White); ${ }^{86}$ two did not address the issue (Justices Blackmun and Pow-

81. 412 U.S. 94 (1973).

82. Id. at $97-98$.

83. Id. at $112-13,130$.

84. Id. at 97, 121 (Burger, C.J., \& Rehnquist, Stewart,.J.J., concurring) ("the concept of private, independent broadcast journalism, regulated by Government to assure protection of the public interest ... could not coexist with a reading of the challenged conduct of the licensee as governmental action").

85. Id. at 70-71 (Brennan, Marshall, J.J., dissenting).

[G]iven the confluence of these various indicia of "government action"-including the public nature of the airwaves, the governmentally created preferred status of broadcasters, the extensive Government regulations of broadcast programmiug, and the specific government approval of the challenged policy-I can only conclude that the Government "has so far insinuated itself into a position" of participation in this policy that the absolute refusal of broadcast licensees to sell airtime to groups or individuals wishing to speak out on controversial issues of public importance must be subjected to the restraints of the First Amendment.

Id. at 180-81 (footnotes omitted).

86. Id. at 146 (White, J., concurring) (although conduct of broadcasters should not always or even often be considered government action, it is "at least arguable, and strongly so," that the Communications Act and FCC policies, including fairness doctrine, are "sufficiently implicated" herc to require first amendment review). 
ell); $; 8$ and one concurred in the plurality opinion but stated his own view that licensing of private conduct makes it state action (Justice Doug1as). ${ }^{88}$ One conclusion that can be drawn from this lack of consensus is that FCC licensing and regulation alone does not satisfy the first amendment's state action requirement in the context of broadcasting. ${ }^{89}$

But state governments also oversee public broadcasting in a number of ways. Althougl the approaches states follow vary, most have enacted their own legislation inodeled on the PBA and have placed public broadcasting under direct state government supervision. ${ }^{90}$ The supervisory authorities differ from state to state and include boards of education, ${ }^{91}$ state universities, ${ }^{92}$ boards of regents, ${ }^{93}$ departinents of general services, ${ }^{94}$ superintendents of public instruction, ${ }^{95}$ and some specially created "takeover" commissions. ${ }^{96}$ And a few states liave created state coordinating

87. Id. at 148 (Blackmun, Powell, J.J., concurring) (since Court concluded that the first amendment does not compel a right of access for editorial broadcasts, government action issue does not affect outcome of the case).

88. Id. at 150 (Douglas, J., concurring) ("activities of licensees of the government operating in the public domain are government actions"). Justice Douglas has argued repeatedly that government licensing of an activity constitutes sufficient government involvement to qualify that activity as state action subject to constitutional standards. See, e.g., Lombard v. Louisiana, 373 U.S. 267, 283 (1963) (Douglas, J., concurring) ("State's interest in and activity with regard to its restaurants extends far beyond any mere income-producing licensing requirement"); Garner v. Louisiana, 368 U.S. 157, 183-85 (1961) (Douglas, J., concurring) (licensing and regulation of restaurant made it a "public facility" whose operations should qualify as state action) (majority decided case on narrower grounds).

89. See Jaffe, The Editorial Responsibility of the Broadcaster: Reflections on Fairness and Access, 85 HARV. L. REv. 768, 784 (1972); see also Walden, supra note 22, at 297-98 (discussing Supreme Court's fractured opinions regarding state action in the $C B S$ case).

Licensing schemes in other contexts also have failed to satisfy the state action requirement. See, e.g., Moose Lodge No. 107 v. Irvis, 407 U.S. 163, 164 (1972) (6-3 decision rejecting claim that private club's discrimination was state action because the club had state license to serve liquor). But see L. Tribe, American Constitutional Law 1719-20 (1988) (in Moose Lodge and Columbia Broadcasting System, government licencing constituted government action that would be subject to constitutional testing).

90. R. Sadowski, AN ANalysis of Statutory Laws Governing CoMmercial and EdUCATIONAL BRoAdCASTING IN THE FIFTY STATES 59-60 (1979).

91. See Del. Code ANN. tit. 14, §§ 129-130 (1981); Fla. Stat. \$§ 229.805, 230.59, 235.40 (1988 Supp.); OR. Rev. STAT. § 354.090 (1987); R.I. GEN. LAWS § 16-61-1 to -8 (1988); TENN. CODE ANN. § 49-50-901 to -909 (1983 \& Supp. 1988).

92. See ME. REv. STAT. ANN. tit. 20-A, $\$ \S 802-803$ (1964), $\S \S 852-853$ (1964 \& Supp. 1988); VT. STAT. ANN. tit. 16, § 2801 (1982).

93. N.Y. EDUC. LAW $\S \S 213,236,414-a$ (McKinney 1988).

94. See CAL. Rev. \& TAX. CodE $\S \S 214,215.5,225.5$ (West 1987 \& Supp. 1989).

95. See Mont. Code ANN. $§ 20-3-105(2)$ (1987).

96. R. Sadowski, supra note 90 , at 196-97. See AlASKa STAT. $\$ 44.21 .256$ (1984); ARK. STAT. ANN. § 6-64 (1947 \& Supp. 1983-84); MD. EDUC. CoDE ANN. § 24-201 (1988); MASS. GEN. LAWS ANN. ch. 6, $\S 158$ (West 1989); NEB. REV. STAT. $\S 72-718.03$ (reissue 1986), id. at $\S 79-2101$ (reissue 1987 \& Supp.); N.J. STAT. ANN. $§ 48: 23-1$ to -10 , (West Supp. 1989); OkLA. STAT. ANN. tit. 70, $\S \S 23-101,2166,2167$ (1989); PA. STAT. ANN. tit. 71, § 1188.1 (Purdon Supp. 1989); id. tit. 24, 
and advisory commissions that allow public stations greater operating independence than do supervisory authorities. ${ }^{97}$ For state action purposes, however, a distinction must be drawn between regulatory action by the state agencies theinselves (always state action) and the conduct of individual public stations that are regulated by state agencies (arguably state action). In a nuinber of cases, the Supreme Court has held that various private enterprises are not involved in state action even though they are regulated significantly by governinent coinmissions and agencies. 98

Although licensing and regulation alone are probably insufficient to constitute state action, federal and state governments also subsidize and fund public broadcasting. In 1987, the federal government provided $18.7 \%$ of public broadcasting's funds through CPB and other governinent grants and contracts. ${ }^{99}$ State and local governments provided an additional $30.0 \%$ through governinent subsidies and funds budgeted through tax-supported colleges and universities. ${ }^{100}$ Despite the large proportion of public funds, ${ }^{101}$ the receipt of government funds alone does not inake an otherwise private actor a state actor for constitutional purposes. ${ }^{102}$ In a series of recent cases, the Suprenie Court has held that government involveinent through subsidies is insufficient to neet the state action requirement. ${ }^{103}$

$\S \S 5-523,5-525$ (Purdon 1962 \& Supp. 1989); id. tit. 24, § 2822(3) (Purdon 1962); S.D. CoDified

LAws ANN. § 13-47-1 to -23 (1982 \& Supp. 1989); W1s. STAT. ANN. § 36.25(5) (West Supp. 1988).

97. For state public broadcasting under coordinating commissions, see LA. REv. STAT. ANN. $\S 17: 2501-03$ (West 1982); OHIo Rev. Code ANN. § 3353.01-02 (1985); UtAH CODE ANN. § 548 b-1 to -9 (1986 \& Supp. 1989); VA. CODE ANN. § 2.1-563.26 (1987); W. VA. CODE $\S 10-5-1$ to -5 (1984 \& Supp. 1989). For those states organized under advisory committees, see N.D. CENT. CoDE $\S \S 15-11-27,15-47-36,15-65-01$ (1971 \& Supp. 1989); WASH. REv. CODE ANN. § 284.91.100 to .120 (1982).

98. See, e.g., Jackson v. Metropolitan Edison Co., 419 U.S. 345, 359-60 (1974) (privatelyowned utilities company not involved in state action despite state regulation); Public Utilities Comm'n v. Pollack, 343 U.S. 451, 465 (1952) (regulatory supervision by Public Utilities Commission did not satisfy state action requirement).

99. STATISTICS, supra note 20, at 15.

100. Id.

101. In 1988, private groups provided just a little under fifty percent of public broadcasting funds. The contributors included subscribers (21.2\%), businesses (15.1\%), foundations (3.7\%), private colleges and universities $(2.8 \%)$, other sources (6.5\%). Id.

102. See generally J. NowAK, R. RorUNDA, \& J. YouNG, supra note 77, at 445 (further government involvement besides receipt of government funds must be shown before Constitution limits action of private parties).

103. See, eg., Blum v. Yaretsky, 457 U.S. 991, 1001 (1982) (no state action when private nursing home received reimbursement from state for Medieaid care); Rendell-Baker v. Kohn, 457 U.S. 830, 832 (1982) (actions by private school receiving income primarily from public sources and regulation by state authorities does not constitute state action); see also L. TRIBE, supra note 89, at 1716-17 (in Blum and Rendell-Baker, despite bulk of funds from government and heavy state regulation, Court still did not find governments responsible for specific decisions giving rise to compaint). 
Altliough government licensing, regulation, and funding of public stations do not add up to state action, the editorial and operational decisions made by a public station licensed to a government entity do constitute state action for first amendment purposes. ${ }^{104}$ For example, if the FCC grants a state university a license to operate a public station, in assessing a first amendment claim a court would consider the station's editorial, adininistrative, policy, and personnel decisions to be state action subject to first amendment review. ${ }^{105}$ Applying the liolding of a number of courts, the same conclusion would apply to the following entities acting in their capacity as public station licensees: boards of education, ${ }^{106}$ boards of regents, ${ }^{107}$ commissioners of education, ${ }^{108}$ state agencies, ${ }^{109}$ municipal officials, ${ }^{110}$ and educational institutions. ${ }^{111}$ And

104. The federal statutory scheme for public broadcasting provides a means of classifying public stations according to the status of the licensees. Beginning with the Educational Television Facilities Act of 1962, the statutory provisions have allowed for five classes of eligible applicants for grants under the federal programs: (1) state or local public school agencies; (2) state public broadcasting agencies and commissions; (3) state-supported colleges and universities; (4) nonprofit community corporations and associations organized primarily to engage in public broadcasting; and (5) municipalities operating public broadcasting stations. See S. REP. No. 93-123, Authorization for Public Broadcasting, 93d Cong., 1st Sess. 4 (1973) (remarks of Sen. Pastore). According to this classification, only the nonprofit community organizations and associations for public broadcasting would not meet the state action requirement.

105. See, e.g., Gay and Lesbian Students Ass'n v. Gohn, 850 F.2d 361, 365-66 (8th Cir. 1988) (state action present in refusal of funding request because university official had final say in decisions through appeals procedure); Gay Lib v. University of Missouri, 416 F. Supp. 1350, 1371 (W.D. Mo. 1976) (state action in state university's recognition of campus organizations), rev'd on other grounds, 558 F.2d 848 (1977), cert. denied, 434 U.S. 1080 (1978); Florida State Univ. Chap., Local 1880 v. Florida Bd. of Regents, 355 F. Supp. 594, 596 (N.D. Fl. 1973) (state university president is agent of state satisfying state action requirement).

106. See, e.g., Florida Bd. of Regents, 355 F. Supp. at 596 (state board of education and commissioner of education agents of state satisfying state action requirement); Alexander $\mathrm{v}$. Thompson, 313 F. Supp. 1389, 1391 (C.D. Ca. 1970) (local school board's conduct constituted state action); NAACP v. Lansing Bd. of Educ., 429 F. Supp. 583, 617 (W.D. Mich. 1976) (state board of education's conduct satisfied state action), aff'd, 571 F.2d 582, cert. denied, 438 U.S. 907 (1978); Oliver v. Kalamazoo Bd. of Educ., 368 F. Supp. 143 (W.D. Mich. 1973) (same), aff'd, 508 F.2d 178 (6th Cir. 1974), cert. denied, 421 U.S. 963 (1975); Hart v. Community School Bd., 383 F. Supp. 699, 748 (1974) (municipal board of education is an agent of state for state action purposes), aff'd, $512 \mathrm{~F} .2 \mathrm{~d}$ 37 (2d. Cir. 1975).

107. See, e.g., Florida Bd. of Regents, 355 F. Supp. at 596 (state board of regents agent of state satisfying state action requirement).

108. See, e.g., Dunham v. Pulsifer, 312 F. Supp. 411, 416 (D. Vt. 1970) (superintendent of education is state agent for state action purposes).

109. See, e.g., Moose Lodge No. 107 v. Irvis, 407 U.S. 163, 179 (1972) (state action present in conduct of state administrative and regulatory agencies, although not in in conduct of private club with state liquor license); Robinson v. Florida, 378 U.S. 153, 156 (1964) (state action in decisions of state's administrative and regulatory agencies just like legislative decisions); Avery v. Midland County, 390 U.S. 474, 480 (1968) (state action by state's political subdivisions); Muhammad Ali v. Division of State Athletic Comm'n of Dep't of State of N.Y., 316 F. Supp. 1246, 1250 (S.D.N.Y. 1970) (act of state's duly constituted agency deemed state action). But see Haris v. Hubbert, 588 F.2d 167, 168 (5th Cir. 1979) (Alabama Education Association not state agency for state action 
since over two-thirds of the stations receiving federal funds from the CPB in 1988 were licensed to state and municipal government licensees, ${ }^{112}$ courts should conclude that the actions of a large number of public stations satisfy the state action requirement.

Important policy reasons also support this conclusion. Courts acknowledge that the FCC grants the licensee-wliether a government agent or a private party-discretion to make editorial and operational decisions. ${ }^{113}$ A government licensee with such wide-ranging discretion and authority, however, must also be responsible for respecting free speech rights. If courts routinely held that the state action requirement was not satisfied in public broadcasting, then courts would never reach the inerits, and the nature and limitations of the public's collective first amendment rights vis-a-vis the government licensee's statutory rights would not be determined. Additionally, courts should regard public broadcasters' actions as constituting state action since the public correctly associates these stations witl the government institutions that operate tliem. Whereas many people would admit that commercial stations may operate as they choose witlin the confines of government regulation, the public could not help but smell government impropriety when a public station's conduct openly and obviously violates free speech rights. Finally, the courts' failure to hold that a government licensee's conduct constitutes state action would stand outside of a line of other state action precedents that regard conduct by state and municipal institutions as

purposes but rather a voluntary, self-supported group of teachers and administrative supervisors with many nonpublic employee members).

110. See, e.g., Lombard v. Louisiana, 373 U.S. 267, 273-74 (1963) (decisions of municipal executive body constitute state action); Southeastern Promotions, Ltd. v. Charlotte, 333 F. Supp. 345 (W.D.N.C. 1971) (use of municipal auditorium constitutes state action); Bennett v. Gravelle, 323 F. Supp. 203, 217 (D. Md.) (Washington Sanitation District Commission and commissioner's action are state action), aff'd, 451 F.2d 1011 (4th Cir. 1971); Ruffin v. Housing Auth., 30I F. Supp. 251, 254 (E.D. La. 1969) (municipal"housing authority is state agent for state action purposes).

111. Guadalupe Org. Inc. v. Tempe Elementary School Dist. No. 3, 587 F.2d 1022, 1026 (9th Cir. 1978) (public elementary school's curriculum choice constituted state action).

112. See STATISTICS, supra note 20, at 10 (213 out of 309 public radio stations licensed to state colleges and universities (180), municipal school districts and governments (20), and state governments and broadcasting authorities (13); 222 out of 324 public television stations licensed to state colleges and universities (86), municipal districts and governments (13) and state governments and broadcasting authorities (123)).

113. See, e.g., Columbia Broadcasting Sys. v. Democratic Nat'1 Comm., 412 U.S. 94, 124 (1969) ("For better or for worse, editing is what editors are for; and editing is selection and choice of material."). But see CBS, Inc. v. FCC, 453 U.S. 367, 396-97 (1981) (Court upheld $\$ 312$ of Communications Act granting right of access to federal candidates because limited right of access does not impair editorial discretion of broadcasters). 
state action under the first amendment and other constitutional provisions. ${ }^{114}$

\section{B. A Standard for Testing Claims Based on the Public's Collective First Amendment Rights}

1. A Standard to Test Licensee Conduct. After determining that a licensee's conduct is state action, courts should proceed to the merits of a viewer's or listener's claim against a licensee. Evaluating these claims requires a standard for testing hicensee conduct. This standard must weigh the public's right to a balanced presentation against the interests the government hicensee asserts to justify its infringing conduct. In addition to this balancing function, the standard must reflect the Supreme Court's special treatment of the federally regulated broadcasting media.

Although the Supreme Court has developed alternative first amendment standards to accommodate the FCC's licensing and regulatory authority, ${ }^{115}$ the Court has not yet apphed these standards to a claim brought against a government licensee involved in public broadcasting. In FCC v. League of Women Voters, ${ }^{116}$ the Court's only case involving a public station, the plaintiffs brought their claim against the FCC rather than the stations tliemselves. The League of Women Voters of California, an individual listener and viewer of certam public stations, and the licensee of those stations-Pacifica Foundation (a private nonprofit corporation unassociated with state or local government)-all brought an action in federal district court against the FCC challenging the constitutionality of section 399 of the PBA. ${ }^{117}$ Section 399 prohibits public stations receiving federal funds through $\mathrm{CPB}$, like those stations operated by Pacifica, from broadcasting editorials. ${ }^{118}$ The Supreme Court lreld, in a five-to-four decision, that the PBA ban against editorializing was unconstitutional. ${ }^{119}$

114. See supra notes 104-12 and accompanying text. The difficult cases for first amendment analysis involve privately-owned noncommercial stations, like the one operated by the Pacifica Foundation in League of Women Voters. See FCC v. League of Women Voters, 468 U.S. 364, 370 (1984). These non-government licensees are more similar to commercial station licensees for state action purposes.

115. See supra note 1.

116. 468 U.S. 364 (1984).

117. Id. at 364, 370. Section 399, as amended by the Pnblic Broadcasting Amendments Act of 1981, forbids any "noncommercial educational broadcasting station which receives a grant from the Corporation" to "engage in editorializing." 47 U.S.C. $\$ 399$ (1982).

118. League of Women Voters, 468 U.S. at 370 \& n.7.

119. Id. at 395. This case provides an interesting comparison to the commercial broadcasting case, Columbia Broadcasting Sys. v. Democratic Nat'l Comm., 412 U.S. 94 (1972). Columbia Broadcasting Sys. involved a private party challenge to a (private) commercial station's policy against editorial advertisement. In that case the first amendment balance favored the private broad- 
Although the claims in League of Women Voters challenged an FCC regulation and not a government licensee's editorial decision, the Court nevertheless established a standard of review that should apply more broadly in other broadcasting cases. Under that standard, the courts should sustain restrictions that infringe on the public's right to a balanced presentation only if the restriction meets two conditions: The restriction (1) is narrowly tailored, and (2) furthers a substantial public interest. 120 Justice Brennan, writing for the majority in League of Women Voters, considered whether to adopt a more stringent standard requiring a compelling government interest-the standard by which courts have traditionally reviewed speech ${ }^{121}$ - but instead adopted an intermediate standard of review because of the technological and historical distinctions that courts have made for broadcast speech. ${ }^{122}$

Although League of Women Voters did not involve a claim against a government licensee of a public station, the standard enunciated by the

caster and the Court refused to authorize further government regulation mandating a right of access for editorial advertisements. See supra notes 81-83 and accompanying text. In League of Women Voters, however, the private parties and public broadcasters (licensed to a private, nonprofit corporation) joined to challenge the statutory prohibition against editorial advertisements. In this case, the Supreme Court struck down the government regulation that limited broadcaster discretion and violated the public's first amendment rights. 468 U.S. at 395 . The similarities and differences of the two cases highlight the importance of taking into account the procedural posture of a case when sorting out competing first amendment claims. Although helpful in the analysis, neither casc involves the procedural and substantive complications that this Note addresses-when private parties' first amendment rights are pitted against the discretion of a government licensee.

120. League of Women Voters, 468 U.S. at 380, 395.

121. Id. at 378-80 ("the absolute freedom to advocate one's own positions without also presenting opposing viewpoints-a freedom enjoyed, for example, by newspaper publishers and soapbox orators-is denied to broadcasters"); see also Miami Herald Publishing Co. v. Tornillo, 418 U.S. 241, 256 (1974) (government compulsion of a newspaper to publish that which "reason" says they should not is unconstitutional).

122. League of Women Voters, 468 U.S. at 377-78. Justice Rehnquist's dissent, joined by Chief Justice Burger and Justice White, rejected such a standard based on the doctrine of constitutional conditious. Id. at 407 (Rehnquist, J., dissenting). This doctrine provides that when the government exercises its power to allocate public funds according to the taxing and spending powers, the government may attach conditions to the funds as long as these couditions have a rational relation to Congress's purpose in providing the funds. Cf. Cammarano v. United States, 358 U.S. 498, 513 (1959) (denial of tax deduction for expenditures made to promote or defeat legislation does not implicate constitutionally protected activity). But see Speiser v. Randall, 357 U.S. 513,519 (1958) (state may deny tax exemption to taxpayer eugagiug in certain type of speech-speech advocating overthrow of U.S. government-if individual may be fined or imprisoned for that speech); American Communications Ass'n. v. Douds, 339 U.S. 382, 402-03 (1950) (no statute aimed at the suppression of dangerous ideas, although aimed at the regulation of conduct, may "be made the instrument of arbitrary suppression of free expression views"). In League of Women Voters, Justice Rehnquist's dissent argued that it is rational for Congress to have determined that public taxes should not go to subsidize a station manager's views or support her partisan politics. 468 U.S. at 408. Justicc Rehnquist also stressed that Congress reasonably determined that editorializing should be banned on public stations to avoid the appearance that government sponsors a particular view or political candidate. Id. at 407. 
Court also should apply to those claims. Not only is the standard fair and reasonable, it is consistent with precedent in broadcasting cases. According to that precedent, the Supreme Court has required that the governinent identify a substantial interest that justifies the conduct infringing broadcast speech. ${ }^{123}$ As the Court indicated in League of Women Voters, the broadcasting media "operates under restraints not imposed on other inedia," and these restraimts are designed to "secure the public's First Amendment imterest in receiving a balanced presentation." 124 This intermediate standard also accommodates two important and, in this context, competing concerns im first amendment doctrine: licensees' traditional editorial role and the viewers' right to a balanced presentation. The League of Women Voters standard balances these two concerns agamst one another, taking account of both but giving absolute priority to neither.

2. How to Measure the Substantiality of Government Interests? Although League of Women Voters provides a standard to test the licensee's conduct, it does not offer a basis to ineasure the substantiality of the government's interest. As the Court explained im League of Women Voters, a restriction does not ineet the "narrowly tailored" standard if the substantial interest justifymg that restriction could be "fully satisfied by less restrictive means that are readily available." 125 The Court, however, does not identify which interests, among the inany imterests the licensee might assert, would be substantial. The Court identifies one government interest-ensuring balanced coverage of public issues-that naturally would be substantial given the importance of "balance" in the development of the regulated industry. ${ }^{126}$ While this governinent interest would be the mam interest the FCC would assert to justify its actions as a regulator, it would not necessarily be the interest a government licensee would assert to sustain editorial decisions. Thus, other interests must be identified and evaluated in order to adapt the League of Women Voters test for use in claims against broadcasters. Muir v. Alabama Educational Television, ${ }^{127}$ an important Fifth Circuit en banc decision that imvolved clains agamst a government public station licensee and was decided

123. See, e.g., Red Lion Broadcasting Co. v. FCC, 395 U.S. 367, 385 (1968) (statutory requirement that stations provide reply time to answer personal attacks and political editorials serves public interest in "vigorous debate on controversial issues of importance and concern").

124. Id. at 380 .

125. Id. at $395,399$.

126. Id. at 378 .

127. Muir v. Alabama Educ. Television Comm'n, 688 F.2d 1033 (5th Cir. 1982), cert. denied, 460 U.S. 1023 (1983). The companion case to Muir is Barnstone v. University of Houston, KUHTTV, 688 F.2d 1033 (5th Cir. 1982). 
before the Supreme Court's decision in League of Women Voters, further clarifies how a court would measure the substantiality of a government licensee's interest. ${ }^{128}$

In Muir the Fifth Circuit sitting en banc heard two cases in which the district courts had reached opposite results in reviewing claims against two public stations. In both cases, public station viewers had sought injunctions compelling the stations to broadcast a cancelled program, "Death of a Princess." 129 On appeal, the viewers argued that the courts' recognition of their first amendment rights limited the discretion the government licensee could exercise in making programming decisions. ${ }^{130}$ A plurality of the Fifth Circuit, however, rejected that argument, holding that viewers can not compel public stations to broadcast cancelled prograins since these stations, according to first ainendment doctrine, are not public forums. ${ }^{131}$ In the plurality's view, Congress, by

128. Muir, 688 F.2d at 1033.

129. Id. at 1036 ("Program is a dramatization of the investigation into the motivations and circumstances which (allegedly) led to the July 1977 execution for adultery of a Saudi Arabian princess and her common lover."); see also infra notes 147-52 and accompanying text.

130. Muir, 688 F.2d at $1036-37$.

131. Id. at $1042-43,1046-47$. Judge Hill's plurality opinion relied on a rather mechanical application of public forum analysis to explain the result. The viewers had argued that the stations, as public forums, are prohibited from making programming decisions motivated by hostility to the program's message and stemming from a specific viewpoint of the broadcaster. Id. at 1041. Judge Hill pointed out that a facility is a public forum only if it is designed to provide a general public right of access or if there is a historic right of access. Since the government has not designated public stations as public forums, the opinion concluded, viewers have no right of access. Id. at 1042.

The opinion pointed out that facilities such as municipal auditoriums, Southeastern Promotions Ltd. v. Conrad, 420 U.S. 546, 552 (1975), bus terminals, Wolin v. Port of New York Auth., 392 F.2d 83, 89 (2d Cir.), cert. denied, 393 U.S. 940 (1968), airports, Chicago Area Military Project v. City of Chicago, 508 F.2d 921, 926 (7th Cir.), cert. denied, 421 U.S. 992 (1975), high school auditoriums, National Socialist White People's Party v. Ringers, 473 F.2d 1010, 1014 (4th Cir. 1973), public libraries, Brown v. Louisiana, 383 U.S. 131, 139 (1966) (plurality opinion), and welfare offices, A1bany Welfare Rights Org. v. Wyman, 493 F.2d 1319, 1323-24 (2d Cir.), cert. denied, 419 U.S. 838 (1974), had been recognized as public forums, but not public stations, Southeastern Promotions, Ltd. v. City of West Palm Beach, 457 F.2d 1016, 1019 (5th Cir. 1972).

The court in Muir relied on the test used in Southeastern Promotions, Ltd. v. City of West Palm Beach, 457 F.2d 1016, 1019 (5th Cir. 1972). The test was formulated in Wolin v. Port of New York Auth., 392 F.2d 83, 89 (2d Cir.), cert denied, 393 U.S. 940 (1968).

[D]oes the character of the place, the pattern of usual activity, the nature of its essential purpose and the population who take advantage of the general invitation extended make it an appropriate place for communication of views on issues of political and social significance.

Muir, 688 F.2d at 1042 .

The plurality's reliance on public forum doctrine drew strong criticism from Judge Rubin in his concurring opinion. Id. at 1048 (Rubin, J., concurring). Rubin initially pointed out that the term "public forum" is not a definition, but is a conclusion. Id. A public forum, he explained, is a label describing a location whose use is open to the public. Id. The public fornm doctrine governs the freedom of expression im streets and other areas that, by tradition, serve as platforms for expression free from content control and subject only to reasonable restrictions of time, place, and manner. This doctrine, according to Judge Rubin, cannot dictate limitations the first amendment might im. 
enacting the PBA, had determined that the first amendment rights of public television viewers were adequately protected under a regulatory system that gave the licensee sole programming discretion but also required the licensee to serve the public interest. ${ }^{132}$

In a special concurrence to the plurality opinion in Muir, an opmion that a Eleventh Circuit panel later described as the holding of the Muir case, ${ }^{133}$ Judge Rubm focused not on the public forum doctrine but rather on a licensee's (statutory) duty to serve the public's interest in program selection. ${ }^{134}$ In his concurrence, Judge Rubin emphasized that the balancing of rights and imterests must take into account the station's "function" or "mission," as specified in its license and its normal operation:

Licensing is not destiny. That the state is the licensee does not predetermine the station's function. The state may elect the station's mission, so long as this mission is consistent with the station's license and the Constitutiou. The prerogatives of managers, editors, and programmers, the rights of access of those who seek exposure, and the rights of viewers, as well as the prerogatives of the licensee itself as a state agency, are at least in large part determined by this inission. ${ }^{135}$

In Judge Rubim's view, courts should determine and evaluate a government licensee's "substantial interests" with reference to the station's mission or function. ${ }^{136}$ That function, as described by the station's license and its normal operational practice, ${ }^{137}$ sets a normative standard for evaluating the station's future conduct. By looking to that underlying function, a court can determine whether an interest asserted by a government licensee is substantial enough to justify conduct infringing the public's collective first amendment rights. If the asserted interest serves the

pose on the government's operation of a medium of communication. Id. Judge Rubin essentially reframed the issue of the case as this Note has done: The issue is "how . . . the first amendment control[s] state action when the state is operating a television station?" Id. at 1049.

132. Id. at 1041 .

133. Schneider v. Indian River Community College Foundation, 875 F.2d 1537, 1541 (11th Cir. 1989). The court explained in Schneider that Judge Rubin's special concurrence, as the "narrowest concurrence, is the holding of the case," absent a majority opinion. Id. at 1541 (in en banc decision involving twenty-two judges,' Judge Hill's opinion was jomed by nine judges and concurred with by another in a separate opinion; Judge Rubin's special concurrence was joined by three judges); see also, e.g., Marks v. United States, 430 U.S. 188, 193 (1977) ("When a fragmented Court decides a case and no single rationale explaining the result enjoys the assent of five Justices, the holding ; of the Court may be viewed as that position taken by those Members who concurred in the judgments on the narrowest grounds . . . ." (quoting Greg v. Georgia, 428 U.S. 153, 169 n.15 (1976) (Stewart, Powell, \& Stevens, J.J., plurality)). The Eleventh Circuit panel's characterization of Judge Rubin's opinion as the narrowest one, rather than Judge Hill's opinion, is convincing, especially since Judge Hill was the one who characterized it that way in the majority opinion in Schneider. See Schneider, 875 F.2d at 1539.

134. Id. at 1048 (Rubin, J., specially concurring).

135. Id.

136. Id. at 1050-51.

137. Id. at 1049. 
station's underlying function, then it will likely be "substantial" for first amendment purposes. For example, if a state university station is shown to be a "magazine of the air," providing "general news dissemination" or "free exposition of ideas," then the government's interest in maintaining audience interest probably would not be substantial enough to justify certain restrictions of the station's news coverage. ${ }^{138}$

This standard of evaluation places some obvious linits on the range of government interests that can be asserted under the League of Women Voters balancing test. Because a government licensee must serve the public interest, ${ }^{139}$ the licensee could not assert a private or personal interest as justification for conduct infringing the public's first annendment rights. For example, an Islamic public station manager could not decide to quit airing the "McNeil/Lehrer News Hour" because an episode involved an interview with author Salman Rushdie. 140 Indeed, a court faced with such a claim would never reach the League of Women Voters analysis: Because a personal interest is not a governmental interest, the court could reject that interest as a justification for the state's conduct without even considering the interest's substantiality.

Thus, in evaluating claims against public broadcasters based on the public's right to a balanced presentation, courts must deternine whether the government hicensee's conduct furthers a substantial government interest and is narrowly tailored to serve that interest. ${ }^{141}$ An interest unrelated to the government's role as a broadcast licensee would provide no justification for infringing conduct. Moreover, as Judge Rubin articulated the standard in Muir, the government's asserted interests must further the mission of the station. ${ }^{142}$

\section{Three Hypothetical Claims Against Public BROADCASTERS}

In order to demonstrate the application of this test for claims against public broadcasters, this Note considers three hypothetical cases.

\section{A. A Hypothetical Case}

Suppose a local umiversity radio station broadcasts a series of interviews with hometown physicians discussing health risks that women incur from abortions performed during the first eight weeks of pregnancy. The station then cancels a prograin presenting "the other side," a report

138. Cf. id. at 1050.

139. See supra note 11 and accompanying text.

140. S. Rushdie, The Satanic Verses (1989).

141. See supra notes $115-24$ and accompanying text.

142. See supra notes 125-37 and accompanying text. 
on new techniques that promise to reduce abortion risk even further below the health risks incurred by women who carry to full term, upon the urgent request of the university president, the station's nommal licensee. As a matter of public knowledge, the university president has made large contributions to a national lobbying group organized to persuade states to enact legislation further restricting abortion following the Supreme Court's recent decision allowing such restrictions, Webster v. Reproductive Health Services. ${ }^{143}$ The university president also has been active in a local group dedicated to electing conservatives to the state legislature. The public radio station receives listeners' letters protesting the cancellation and in response to their demands for an explanation from the station, the university president flatly refuses to comment.

As a result, several histeners file a class action suit in federal district court agamst the licensee on belialf of the entire public radio audience in the histening area. Their complaint alleges that by cancelling the program, the hicensee (the university president) interfered with the station's normal operation by professional journalists and thus violated the listeners' right to a balanced presentation on issues of public concern, as guaranteed by the first and fourteentl amendments. The viewers seek an injunction compelling the station to air the program. In response to the complaimt, the umiversity president argues that FCC policy vests absolute discretion for program selection $\mathrm{m}$ the licensee, and his decision to cancel the program was an authorized exercise of that discretion.

Under the public broadcasting test proposed in this Note, the listeners in this case would win; a court would enjoin the public station to reschedule the cancelled progrant. The listeners' first amendment right to a balanced presentation establishes a presumption that the public station should not cancel a prograin responding to the one that highlighted only the liealth risks of abortion. In order to overcome this presumption, the government licensee must identify a substantial government interest justifying its decision to cancel the second program. ${ }^{144}$

In order to provide sucli a justification, the licensee's personal opposition to abortion, for example, would not satisfy the standard because it is not even a government interest. ${ }^{145}$ If the licensee were able to identify another interest, sucl as an interest in public health and norality, the court then would consider that interest's substantiality. So vague a government interest, lowever, probably would not satisfy the substantiality requirement with the degree of specificity that Judge Rubim's concurring

143. Webster v. Reproductive Health Servs., 109 S. Ct. 3040 (1989).

144. If the licensee refused to identify any government interest, the court would rule summarily for the listeners as a matter of law.

145. See supra notes 138-39 and accompanying text. 
opinion in the Muir case requires. ${ }^{146}$ Although the interest in public health and morahty is a government interest, it is not clear that such an interest furthers the mission of the station. As the court would find, based on the station's normal operation and the terms of its license, the station's mission is in part to keep the public abreast of important medical developments-inatters of public concern, especially to a listening audience in a unnersity commumity. To the extent that the interest in public health and morality is inconsistent with the station's mission, that interest would not justify this station's decision to cancel the broadcast.

Fimally, the licensee also may encounter difficulty establishing the substantiality of this interest because tlie president is merely a nominal licensee, rarely involved in the station's day-to-day programming decisions or normal operation. Because the station's day-to-day operators would be in the best position to fulfill the station's mission of keeping the public abreast of important developments, the courts may not consider any interest that a nominal licensee asserts as substantial enough to justify an unusual interruption of the stations' normal operations without corroboration by station operators.

\section{B. More Substantial Government Interests: Muir v. Alabama Education Commission}

This first hypothetical illustrated a relatively clear case in which a government licensee was unable to identify a government interest justifying its decision to cancel a controversial program. ${ }^{147}$ In many cases, however, the government licensee may be able to identify a variety of government interests. In those cases, a court then inust evaluate whether the interests are substantial enougli and whether the licensee's restrictive action was narrowly tailored to serve that interest. ${ }^{148}$ An interest is substantial when it furthers the mission of the station according to its nor* mal operation and the terms of its license, ${ }^{149}$ and a narrowly tailored restriction serves an interest that could not be "fully satisfied by less re-

146. See supra notes 132-37 and accompanying text.

147. Is the outcome in this case really clear, or rather does the result make sense because of the general public's acceptance of the possibility of two legitimate, but opposing, viewpoints? Consider, for example, whether smokers joined by RJR Nabisco to challenge the cancellation of a program questioning the link between lung cancer and cigarettes would win; whether members of the $\mathrm{Ku}$ Klux Klan challenging the cancellation of a news report about demonstrations of White Supremacists in Forsythe County would win; or whether an alleged drug czar challenging the cancellation of a program advocating the legalization of drugs would win.

148. See supra notes $115-24$ and accompanying text.

149. See supra notes $125-41$ and accompanying text. 
strictive means that are readily available." 150 The following hypothetical based on the facts in Muir demonstrates this standard's application.

Suppose a number of public television stations in Alabama and Texas schedule a seasonal broadcast of the PBS program series "World." A controversial episode of the series, "Death of a Princess," depicts the July 1977 execution of a Saudi Arabian princess and her commoner lover for adultery. Government licensees in both states decide to cancel the program, and viewers sue in federal court for injunctions to coinpel the broadcast.

In Alabama, the statewide public television network decides to cancel the program on every state channel as requested by inany letters from Alabaina residents. The state hicensee makes this decision based on a widespread behief that the personal safety and well-being of Alabaina citizens working in the Middle East would be threatened if the program were shown.

In Texas, the government hicensee of one public station, a Umiversity of Houston official, decides not to broadcast "Death of a Princess" for other reasons. When questioned about his decision, the licensee offers a number of government interests and concerns in justification for the cancellation: (1) foreign policy concerns (the Saudi government's strong objections to the broadcast in light of the long-time U.S. friendship with Saudi Arabia and respect for the volatility of events in the Middle East), (2) concern for the personal safety of another Saudi princess who had been educated at the University, (3) uneasiness about the fact that the program may provide an unbalanced treatment of the incident, (4) fear that the public might mistakenly beheve the "docu-drama" to be a true documentary and thereby be misled, and (5) respect for the oil industry, which contributes significant private funds to the University.

In applying the public broadcasting test, a court wonld first consider whether any of these asserted reasons count as substantial government interests. For example, although the Alabama hicensee's interest in the personal safety and well-being of Alabaina residents is a government interest, the court might not consider it a substantial interest that would justify infringing the public's collective first ainendment right, since it is unconnected to the educational imission of Alabama public television. ${ }^{151}$ On the other hand, the court imgit conclude that the station's dedication to being responsive to public concerns-a legitimate interest that might

150. See supra note 125 and accompanying text.

151. The mission of the stations, in this case, is not the same as the university sponsored public radio station above. See supra notes $142-46$ and accompanying text. The mission of the state-wide network would be broader because it is commissioned by the state legislature to serve the general educational needs of the state-wide viewing public. 
be asserted based on the many letters sent by viewers-is a substantial enough government interest.

With respect to the reasons asserted by the Texas licensee, its foreign policy concerns would fail for the same reason that the Alabama licensee's personal safety and well-being interest failed: Although foreign policy is a legitimate government interest, it has no relation to the government licensee's interest in furthering the station's mission. Second, the licensee's concern for the other Saudi princess previously educated at the University is difficult to evaluate as a public reason, altlough it may indicate a well-intended effort to respect the royal family's personal affairs because of past associations. This privacy or loyalty concern probably would not be more substantial than the public's first amendnent right to a balanced presentation because it also is unrelated to the station's mission.

The Texas licensee's final three concerns-for the unbalanced treatnient and misleading nature of the program, and deference to the oil industry-probably all constitute substantial government interests. The government licensee may well have a substantial interest in whether the program provides a balanced treatment of the incident: Because the licensee has ultimate responsibility to the federal governnient for the con1pliance of a station's programming with FCC requirements, he thus has a substantial interest $\mathrm{m}$ providing a balanced schedule of programs. Likewise, the government hicensee has a substantial interest in the manner of presentation of issues of public concern, which niay well include an interest $i m$ whether viewers perceive the progran to be a documentary rather than a partially fictitious "docu-drama." Both these interests are connected to the station's mission as determined by the terms of its license and nornal operation. Additionally, the government licensee nnay have a substantial interest in the program's effect on oil industry contributions if the industry makes those contributions directly to the station and a loss of those contributions would threaten the station's ability to continue operations at all.

Once the government licensee has established a substantial government interest, then it must prove that its restrictive conduct was narrowly tailored to serve those interests. The court could well find that the government licensees would have been more responsive to the public interest, and its action tailored more narrowly, had it arranged to go ahead and show the prograni and then after the progran broadcast a debate involving Saudi experts about standards of morality and women's roles in royal culture. The licensee also could have run a disclaimer with the program stating that the program was partially fictitious and not a docunentary, thereby alleviating any possible misconceptions. The sanie con- 
cerns about misperception and imbalance would have been served if the station had aired the views on the other side.

The station's imterest in oil industry contributions, however, may justify cancellation-assuming that an absence of oil money would threaten the station's continued operation. The station does not have to commit financial suicide in order to serve the first amendment. A court faced with this situation, of course, would have to evaluate whether the hicensee had available a less restrictive means, such as explaining to the contributors the station's decision to broadcast the controversial program. But if the station's need to protect its funding could "not be fully satisfied by less restrictive ineans that are readily available," 152 then its decision not to broadcast would withstand this challenge.

\section{Professional Employees' Claims: Schneider v. Indian River Comınunity College}

The proposed public broadcast test is framed specifically for claims brought by viewers and listeners against public broadcasters. Since this test is formulated in terms of the public's right to a balanced presentation, courts must inake soine adjustinents to make the test "fit" when deciding claims brought by professional broadcast journalists against governinent hicensees. In these cases the plaintiff, commonly a station inanager or broadcast journalist, asserts that a government licensee's decision abridged einployees free speech rights and, derivatively, the public's collective first amendinent right to access a variety of ideas.

In evaluating a journalist's free speecl rights, courts must account for a government licensee's considerable interests as a public employer. Although a state may not condition public einployment on infrimgement of the journalist's rigltt of free expression, this right is necessarily linited by the public employer's interest in the public service it performs. ${ }^{153}$ In determining the strength of a journalist's claim, the court sliould factor in considerations such as the possible impairment that upholding the claim would have on discipline by superiors or harmony among co-workers, its detrinental impact on close working relations, or its interference

152. See supra note 125 and accompanying text.

153. See Connick v. Myers, 461 U.S. 138, 154 (1983). The test for public employee speech was established in Pickering v. Board of Educ., 391 U.S. 563, 568 (1968), and requires that a court "balance ... the interests of the [employee] as a citizen, in commenting on matters of public concern, and the interest of the State, as an employer, in promoting the efficiency of the public services it performs through its employees." 
with the journahist's ability to perform her duties in the regular operation of the station. ${ }^{154}$

In addition to the journalist's individual free speech rights, the courts inust recognize that this claim also represents the public's collective first amendment rights, albeit in a round-about fashion. When the government is directly involved in editorial decisions about broadcast content, the professional journalist plays a crucial intermediary role between the government, whose interests sonetimes threaten first amendinent values, and the public, who retains its first amendment rights even when the governinent acts as broadcast licensee. ${ }^{155}$ In her role as interinediary, the broadcast journalist inust juggle carefully her duties as a loyal public employee with her professional ethic to serve the public interest by inaking available balanced and accurate information on issues of public concern. With these duties in mind, the professional journalist is often in the best practical position to raise a clain against a public broadcaster who atteinpts to violate the public's first anendment rights by cancelling a program for illegitimate reasons. ${ }^{156}$ The journalist is familiar with professional standards regarding newsworthy information, she knows when the government licensee suppresses important stories, and she is often aware of the trne reasons for these suppressions.

The journalist's claim based on her own free speech rights and the public's first amendment rights presents certain tactical considerations. Since Supreine Court's decision in League of Women Voters has clarified the law concerning suits brought by viewers or listeners, ${ }^{157}$ the journalist might be well advised to have a viewer or listener as a co-plaintiff. The journalist also should file a clain for an injunction, rather than opting for a "self-help" reinedy against the licensee's direct orders: The fact of insubordination might weigh heavily against her in the later lawsuit. ${ }^{158}$

154. Connick, 461 U.S. at 570-73; see also Rankin v. McPherson, 483 U.S. 378, 388 (1987) (court must consider the time, manner, and place of the employees' expression, as well as the entire context).

155. See supra notes 1-6 and accompanying text.

156. The three hypotheticals only discuss the availability of a cause of action arising from the cancellation of a program, a situation more easily identified and redressed than a situation in which a station manager schedules a program addressing one side of an issue and then declines to schedule one on the other side. In the latter case, the public probably never would know such decision was made, and the station manager certainly would not bring a claim challenging his own decision.

157. See supra notes 115-24 and accompanying text.

158. Compare Schneider v. Indian River Community College, 875 F.2d 1537, 1540-44 (11th Cir. 1989) (remanding for factual inquiry regrading all first amendment claims, including retaliatory dismissal) with Schneider v. Indian River Community College, 684 F. Supp. 283, 280, 288-90 (S.D. Fla. 1987) (granting summary judgment for college on first amendment claims because decision in favor of plaintiffs would subject licensees "who are ultimately and solely responsible for all programming content, to the whims and wishes of all subordinate, or in this case, insubordinate employees.). 
A recent Eleventh Circuit decision, Schneider v. Indian River Community College Foundation, illustrates complications that can arise from a journalist's claim. ${ }^{159}$ In Schneider, the station manager and program director of a public radio station filed claims against the government liceusee, Indian River Community College, alleging that college officials had attempted to censor a news story about a nearby industrial development because the story would jeopardize potential contributions to the college foundation. ${ }^{160}$ They also contended that the college suppressed newscasts about a local election because the information 1might have damaged the political career of one of the candidates who also was a close friend of the college president. ${ }^{161}$ The station manager and program director went ahead with the broadcasts in violation of the licensee's order, and they were fired because, as the government hicensee argued, employees' insubordination impaired the station's capacity to fulfill its statutory obligations. ${ }^{162}$ Although the district court dismissed the suit and reprimanded the employees for even brimging it, ${ }^{163}$ the Eleventh Circuit partially affirmed the district court's opinion but reversed and remanded plaintiffs' claim of retaliatory discharge for further consideration by the trial court. ${ }^{164}$

The broadcast journahists clearly liad a difficult claim to establish in this case. Under the analysis proposed by this Note, they would have had an easier case if tliey liad joined a listener as plaintiff and filed for an injunction before the scheduled broadcast. As the case arose, the journalists' insubordinate act imiglit well justify the government licensee's termination of their employment because of the employer's interest in efficient broadcasting. ${ }^{165}$ With a listener as a co-plaintiff, however, a court applying the public broadcasting test imght have reached the opposite result on the first amendinent claims. Under that test, the public's riglit to a balanced presentation would require the government licensee to justify the substantiality of the interest. Moreover, the government licensee's interest in funding from a local industrial development arguably would not be a substantial governinent interest because in this case, it concerned funding for the college foundation and not the station. On the other point, suppression of local election news would not qualify even as a government interest because it was done to protect the political career of the college president's personal friend.

159. 875 F.2d at 1537.

160. Schneider, 684 F. Supp. at 285.

161. Id.

162. $I d$.

163. Id. at 287, 290.

164. Schneider, 875 F.2d at 1545.

165. See supra notes $152-53$ and accompanying text. 


\section{CONCLUSION}

The above hypotheticals illustrate the analysis that courts should use in deciding first amendinent claims against public broadcasters. Such claims, based on the public's collective right to a balanced presentation and possibly professional journalists' free speech riglits, are well-suited for the public broadcasting context because they offer an opportunity for public cliallenges in federal court of government misconduct. In deciding claims against public broadcasters, tlie courts should rely on the proposed public broadcasting standard derived from the Supreme Court's opinion in League of Women Voters and Judge Rubin's special concurrence in the Muir decision. ${ }^{166}$ This standard requires that a licensee identify a substantial government interest and narrowly tailor its infringing conduct to serve that interest. ${ }^{167}$ The substantiality of a governinent interest would be assessed in view of the station's mission as determined from its normal operation and the terms of its license. ${ }^{168}$

Claims based on the public's riglit to a balanced presentation also would serve iniportant policy interests. This cause of action leaves the initiative for complaints witli the injured parties and thus shifts some of the more controversial duties of the FCC back to meinbers of the public, the persons most interested in protecting their own first alnendment riglits. Permitting claims in federal court also checks a government licensee's impropriety, thereby promoting a system of public broadcasting that efficiently and effectively serves the public interest. Finally, the potential for viewers and listeners to sue in federal court will encourage public stations to act responsibly as "public trnstees" wlien operating outside the corrective meclianisms of the inarket. Altliougli government licensees' fear of future litigation could produce a "wlite bread" effect, tliereby decreasing diversity on the airwaves, the possibility of such an effect is not compelling enougli to allow the governinent licensee complete discretion over the public's first amendment riglits.

The court's recognition of tliese claims also would lielp balance the need to clieck the government's abuse of discretion and the public's interest in accessing ideas. Public radio and television stations perform an important service by providing a menu of programs unmatched by commercial stations, contributing in an important way to diversity on the airwaves. But the public must retain some control over its first ainendment riglits when tlie government assumes the role of broadcaster, and

166. FCC v. League of Women Voters, 468 U.S. 364 (1984); Muir v. Alabama Educ. Television Comm'n, 688 F.2d 1033 (5th Cir. 1982) (Rubin, J., specially concurring), cert. denied, 460 U.S. 1023 (1983).

167. See supra notes $115-24$ and accompanying text.

168. See supra notes $\mathbf{1 2 5 - 3 7}$ and accompanying text. 
these private initiative lawsuits would serve the public's iuterests more effectively than the present FCC regulatory scheme. By recognizing these claims and reducing government regulation, the application of the first amendinent to public broadcasting cases would parallel general first aniendment doctrine more closely.

Rebecca L. Torrey 


\section{.}

